\title{
DETERMINANTS WHICH SHAPE CONFIDENCE IN THIRD SECTOR ORGANISATIONS
}

\author{
Małgorzata Marzec*
}

\begin{abstract}
Background. Analysis of the organization of the third sector requires the introduction of new concepts in order to describe and explain the principles of their functioning. NGOs are forced to pay more and more attention to relations with cooperating entities, the so-called stakeholders. Building trust seems to be the way of facilitating cooperation, achieving set goals and developing the organization. An important feature of the third sector organizations is that they arise as a result of the grass-root civic initiative, i.e. people who want to achieve a specific goal. Building optimal, complex interactions with the stakeholders seems to be crucial where achieving the goals of the third sector entities is concerned. This goal can be effectively achieved when cooperation is built on the trust basis. Trust seems to be not only a determinant of shaping the activities of NGOs, but also the effect of their functioning. The article puts forward a thesis that trust is an important factor determining the success of non-profit organizations.
\end{abstract}

Research aims. The aim of the article is to indicate places - relationships and determinants of trust formation, as well systematics of types of trust to non-governmental organizations. The article presents the concept of trust in NGOs taking into account the factors shaping this trust.

Methodology. For the analysis of trust in NGOs, the analysis of the literature on the third sector, management and trust was carried out. The review made it possible to refer knowledge to determine the factors that shape trust in NGOs. The literature analysis has been supplemented with a review of research on operating conditions and assessment of the activities of third sector entities in Poland.

Key findings. The review of literature made it possible to systematise the concept of trust in the organization of the third sector. The analysis of the concept of trust in NGOs indicated the areas of confidence building and the need for further systematic analysis of trust in entities operating in the third sector.

Keywords: trust, NGO, third sector, confidence to NGO 


\section{INTRODUCTION}

An analysis of third sector organisations requires introduction of new concepts for description and explanation of the principles of their functioning. Social economy entities are forced to pay more and more attention to relations with cooperating entities, the so-called interested parties. Building trust seems to be a method which facilitates cooperation, realisation of set objectives and development of an organisation. Trust to NGOs should be higher than trust to commercial organisations founded to achieve maximum profits. Non-Governmental Organisations (NGOs) are private non-profit organisations, which activity is based on cooperation of people who want to achieve an intended objective. An important feature of third sector organisations is that they are formed as a result of a grassroots civil initiative, i.e. people who wish to achieve a particular aim. In the case of third sector entities, cooperation becomes very meaningful (Bogacz-Wojtanowska, 2008, p. 23). Building of optimal complex relations with interested parties seems to be a key method of realising intended objectives of the third sector entities. This objective may be achieved efficiently when cooperation is built based on trust. Trust means a belief or opinion that cooperating people share specific standards and principles and act favourably towards the achieved objective without detriment to the cooperating parties or those who have to benefit from functioning of an NGO. The objective of the article is to indicate places-relations where trust is built, systematics of trust types and define determinants which shape trust in NGOs.

The article comprises four parts. The first one describes the principles of functioning of NGOs. The next one presents the trust concept and indicates the grounds on which trust to non-governmental organisations is formed and built. The last part presents the confidence level in NGOs in Poland and possible strategies of building trust by non-governmental organisations. This article will attempt to assess this issue by analysing the literature and theoretical discussion. Theoretical analysis has been complemented by an overview of trust to NGOs in Poland. 


\section{DESCRIPTION OF THE THIRD SECTOR ORGANISATION WITH REGARD TO TRUST}

Activity of a non-profit organisation is regulated in Poland with provisions of the act on public benefit activity and voluntary work of 2003. However, no explicit definition of this type of organisations may be reported. It is worth to provide here a definition of a modern non-governmental organisation after A. Sargeant, i.e.: "a non-profit organization is an organization which serves improvement of the general level of social life due to collection and redistribution of relevant resources and providing material goods and services" (Sargeant, 2004, p. 17). On the other hand, according to B. Filipiak and J. Ruszała "legal persons or entities with no legal capacity founded based on the provisions of acts, which do not belong to the sector of public finances (under the act on public finances) and not operating in order to gain profit, including funds and associations" (Filipiak \& Ruszała, 2009, p. 110).

An important feature of non-governmental organisations is that they are private non-profit organisations founded by social initiative regardless of the public organisation (governmental or local). Organisations of this type are formed in order to carry out a common purpose. Formation of NGOs results from the development of a civil society development and favours building social capital. Presently, we may report an increase of the significance of non-governmental organisations. It is related to the change of the position of social services' recipients, who more often expect greater innovativeness in realisation of public tasks. Operation of non-governmental organisations may raise the level and quality of satisfaction of social needs. Among the properties of third sector organisations we should list the following: freedom of choice when an organisation is found and carried out, independence of operation (they are not subject to the public authority's control), a non-profit nature of operation (gaining profits is not their fundamental purpose), formal constitution (they function under relevant legal provisions), operation for the benefit of public welfare (they carry out some of the public tasks through provision of public goods) (Janoś-Kresło, 2002 , p. 11). The sector of non-governmental organisations is varied. It includes entities with a varied legal form including funds and 
associations. Generally, these organisations are "not oriented at gaining profits and charitably participate in solving problems including social problems" (Pawłowska, 2015, p. 3). Non-governmental organisations include:

- participatory self-help organisations, providing aid only to their members,

- charitable organisations, which help all entities and people who need help

- representative organisations, which represent a specific society or a group of people,

- minority organisations, which act on behalf of minority groups of various types,

- organisations formed ad hoc, established in order to organise a single action,

- hobby-recreational organisations which join people who share the same passion,

- task organisations, which carry out tasks ordered by the government or local authorities,

- traditional organisations, which act for many people who wish to carry out a common purpose (based on Krzyżanowska, 2000, p. 16; Pawłowska, 2015, p. 3)

The task of non-governmental organisations is satisfying social needs and activating citizens. Besides the realisation of the main objectives, non-governmental organisations play an important function of shaping various cooperation forms in a given local community. Cooperation enables achievement of a specific intended purpose for cooperating entities. Non-governmental organisations enable a dialogue between citizens and governmental or local bodies. They often deal with satisfaction of various and complex needs of a local society. NGOs through their activity cause that public organisations and market may be more responsible for their operation - carry out their tasks more efficiently.

The third sector organisations play a significant role with regard to building social trust. They raise social capital by giving people a chance to build trust in one another and the ability to cooperate in order to carry out common objectives. A common agreement exists that the social capital favours obtaining mutual advantages from joint (group) operation. According to E. Bogacz-Wojtanowska social capital is very precious for non-governmental organisations' operation 
(Bogacz-Wojtanowska, 2013 p. 45). It means that on the one hand, social capital favours functioning of non-governmental organisations and on the other hand, operating NGOs create conditions for building social capital. The indicated capital results from interactions between cooperating units. Moreover, it enables easier access to information and resources indispensable to provide services by non-governmental organisations.

Organisations depend on good relations with the environment. Entities must not only organise their activity but also create good conditions for shaping relations with entities which directly or indirectly cooperate with a particular organisation. Good relations depend on inter alia: paying attention to activity, knowledge, understanding, balance of interests of parties who participate in cooperation (exchange), and trust (Poleszczuk, pp. 105-121). Presently it is expected that organisations will carry out their main objectives, but also act responsibly. Responsibility is related not only to providing good products and services, but also to caring for the interest of all. The manner in which an organisation functions should be credible and trustful. The problem of creating relevant relations with the surroundings, including building trust also concerns non-profit organisations. NGOs should shape trust both in entities cooperating with a given organisation and entities which use the data of a given organisation.

The object of analysis of trust in the case of non-profit organisations may be trust in: offered services (goods), cooperating people (entities), idea or objective indicated by a given organisation as well as trust in non-profit organisations in general. The nature of operation of a non-profit organisation has a significant impact on shaping relations with entities cooperating with NGOs. In the case of all non-governmental organisations, the recipients of services-goods provided by the organisations are a significant group of cooperating entities. Shaping relations between non-profit organisations or donors who fund operation of an organisation will be different and relations between volunteers and NGOs will be built differently. It is worth noticing that the third sector organisations must also include in their activity shaping trust (the so-called atmosphere of trust) towards the non-profit sector.

Shaping trust of clients-recipients in actions offered by organisations of this type should be one of the main grounds for building trust to 
non-profit organisations. Modern non-profit organisations should be set on investigation of clients' needs and preferences. Non-profit organisations act under the principle of feedback. "By operation they use the social capital namely, economic resources which result from social bonds and human contacts, which are based on trust, agreement and cooperation and at the same time their activity leads to multiplication of resources of this type of capital and its mobilization" (Hausner et al., p. 6).

Non-profit organisations whose products may consist of goods which satisfy both social needs and expectations of the members and funders of the organisation, undertake actions aiming at the society or specific funders to encourage them to give money for functioning of a given organisation (Iwankiewicz-Rak, p. 96). Entities which transfer funds to NGOs will support operation of non-profit organisations not only in a situation when they will be convinced to share ideas suggested by particular institutions and in conditions of mutual agreement. Convincing to ideas and mutual agreement may develop in the atmosphere of trust. Trust is a key issue of the third sector organisations' operation. Without trust in particular relations with recipients of an NGO's actions it is difficult to obtain funds for realisation of intended objectives. Trust should be shaped in relation to all groups cooperating (interested parties) with an NGO.

The subject of the article is to analyse trust in entities (of the socalled interested parties), which cooperate directly or indirectly with non-profit organisations. We also made a review with regard to various planes of shaping trust. Trust seems to be not only a determinant of shaping an NGO's operation, but also an effect of their functioning. The article presents a thesis that trust is a significant factor which decides on the success of a non-profit organisation.

\section{TRUST IN THIRD SECTOR ORGANISATIONS}

Trust is an emotion showed to objects, people, and institutions such as an entrepreneur, government, or society. Trust means readiness to undertake activities based on the expectation that the other party will act favourably towards us. Mutual trust is a necessary condition for the functioning of a particular group (persons, entities), but also an effect of group cooperation. Building trust enables cooperation 
between particular entities of exchange. Parties who trust each other may cooperate and achieve designed objectives more easily.

Trust is a concept analysed in a few scientific disciplines. This definition is sometimes understood as "assurance, hope, conviction or a set of beliefs, predisposition, variable of a situation, structure or interpersonal, variable of a social relation of trusteeship" (Lewicka-Strzałecka, 2003, p. 2). There is no interdisciplinary agreement within understanding of this concept. For the purpose of this study, it is worth to quote definitions developed by two researchers of trust. The first one by P. Sztompka, who stated that "we trust a person - entity, when we believe that they will advise us and think about us not about themselves" (Sztompka, 2007, p. 69). The second definition emphasises similar concepts of trust as including advantage. R. Hardin is the author of this definition. He claims that "to trust someone is to believe that this person has good intentions and that he is able to do what we expect from him... To trust someone means to have relevant information on a person who is an object of our trust, in particular concerning its intention towards us" (Hardin, 2009, p. 25).

Most often, we analyse trust as: an element of social capital, social interaction foundation, an organisation's resource, expectation of future actions of other people or groups and as the relations inside a given organisation. Trust is voluntary because partners of a relation take up decision by themselves whether it is worth to trust other parties in the relationship. Trust is related to risk, since each party must take unfairness of the partner and uncertainty of realisation of the effects of relation into account. An important aspect of trust is that one cannot gain it forever. Trust is dynamic and changes in time, which means that it may be lost at any time. Moreover, it is built based on experience and knowledge not only of the entity that wants to trust but also other entities.

The act of placing confidence consists in undertaking actions related to expectations that people and institutions will act favourably towards us. Trust is always related to a conviction that the other part of the relation is fair towards a given entity in their intentions and actions. The table below presents definitions of trust from the perspective of managing the organisation. 
Table 1. Definitions of trust from the perspective of managing the organisation.

\begin{tabular}{|l|l|}
\hline \multicolumn{1}{|c|}{ Author } & \multicolumn{1}{c|}{ Definition } \\
\hline $\begin{array}{l}\text { Paliszkiewicz } \\
(2013)\end{array}$ & $\begin{array}{l}\text { Trust is a belief that the other party will not act to our detriment, } \\
\text { will be reliable, will act predictably and will act in a manner which is } \\
\text { favourable to us }\end{array}$ \\
\hline $\begin{array}{l}\text { Sankowska } \\
(2012)\end{array}$ & $\begin{array}{l}\text { Trust means readiness to be sensitive to actions undertaken by the } \\
\text { other party, based on the assessment of its accountability in } \\
\text { a situation of interdependence and risk }\end{array}$ \\
\hline $\begin{array}{l}\text { Grudzewski } \\
\text { et al. }\end{array}$ & $\begin{array}{l}\text { Trust is a directed relation between two individuals out of which one } \\
\text { is called a trusting person and the other one a trustee. Trust shows } \\
\text { a situation of dependence between a trusting person and } \\
\text { a trustee which bears signs of risk. }\end{array}$ \\
\hline $\begin{array}{l}\text { Gambetta } \\
(1988)\end{array}$ & $\begin{array}{l}\text { Trust is a resource, which is going to cause that economic results will } \\
\text { be achieved; plays an important role in economic life and enables } \\
\text { effective market exchange }\end{array}$ \\
\hline $\begin{array}{l}\text { Mayer et al. } \\
(1995)\end{array}$ & $\begin{array}{l}\text { Trust is a readiness to accept behaviour of the other party without the } \\
\text { necessity to control and monitor his conduct; we are ready to take risk }\end{array}$ \\
\hline $\begin{array}{l}\text { Hardin } \\
(2009)\end{array}$ & $\begin{array}{l}\text { To trust someone means to believe that this person has good inten- } \\
\text { tions and is able to do what we expect }\end{array}$ \\
\hline
\end{tabular}

Source: developed based on Paliszkiewicz, 2013; Kapuścik, 2015; Hardin, 2009; Mayer et al., 1995.

Trust often relates to a belief that the other party of cooperation is fair towards a particular entity in its intentions and actions. Trust may constitute an object of purposeful actions directed at a description of groups or people; it may result from the presence of particular people from the close surroundings (family, friends) or further - people from work or public life. Trust between business partners (co-operators) and trust of society (clients, society, publicity, guardians, etc.) are essential in carrying out any activity. Trust may take various levels in relation to a society and is based on moral foundations and a belief of an individual that the remaining part of the society has the same moral principles. Trust is one of the moral principles. It is often defined as a mental condition including an intention of accepting cooperation offers or their continuance, based on positive expectations (Hardyś, 2008; Besiok, 2013). Each trust simplifies human relations since it is a function of reduction of the complexity level (Praszkier, 2007, p. 4).

An analysis of trust enables us to divide determinants which shape its formation. The following elements can be distinguished the most often: competences, risk, reliability, responsibility, good will, kindness, predictability, and diligence. From the point of view 
of an organisation's functioning, trust is one of the key factors which determine achievement of the intended purpose and development of an organisation and constitutes its non-material value. It builds positive relations both inside a particular organisation as well as with the external environment. Often, a meaning of trust for improvement of efficiency and speed of functioning and creating a positive image of a given entity is indicated.

A detailed analysis of trust is related to distinguishing elements of trust. Most often three groups of factors shaping trust i.e. capacity, kindness, and trust may be distinguished. (Sankowska, 2012 p. 42). Abilities are understood as competences and skills to carry out specific tasks. Kindness is associated with engagement, care, loyalty, availability, and openness to new ideas. Honesty is identified with fairness, fulfilling promises, consequence, and reliability. Distinguished factors gain a special meaning in relations with the interested parties of non-governmental organisations.

Covey, another author of articles related to trust, draws attention to two groups of factors which shape trust. These determinants may include nature and competences (Covey \& Merrill, 2008). The first feature - nature is related to righteousness and intentions. Righteousness means honesty of acts. It is related to solidity and cohesion of functioning of a particular organisation (what happens inside is compliant with what is provided outside). On the other hand, intentions are related to motives of an organisation and intentions from which operation of an organisation results. If the organisation has any hidden objectives it will be hard to believe that the welfare of other entities is its purpose. In case there is no trust based on the nature of an organisation, it would be hard to make entities or cooperating persons trust. The other feature - competences related to the ability and results of operation of a given organisation. Skills are measures which serve achieving an objective. We may list here technical, organisational, and social skills. The last feature is related to the results of operation of an organisation. Results refer to the history of functioning of an organisation and its experience.

The process of building trust between entities may be analysed on three levels, i.e. as cognitive processes, structures and emotional processes, and behavioural mechanisms.

Trust as a cognitive process is related to division of individuals to such whom we trust (namely reliable ones) and such, whom we 
do not trust yet, because we have no knowledge of their functioning. This process of building trust is based on cognition and collection of information on individuals, whom it is worth or not to trust. Cognitive processes do not have to be based only on the individual's experience; they may also be based on knowledge of other cooperating people (who are in a relation) with a given organisation.

Trust based on the structure and emotional processes is related to personal relations of participants to cooperation. This type of trust is shaped based on experience and emotions of entities that directly or indirectly cooperate with each other.

Trust based on behavioural mechanisms is related to undertaking specific actions related to trusting an entity.

Trust is often built in conditions of uncertainty or risk. Thus, we may indicate here two types of trust, blind trust and realistic one (authentic). Blind trust is related to an unconditional belief that one party will not use its advantage to gain favour from cooperation. This type of trust should be shaped by the entire third sector. Blind trust enables construction of the so-called atmosphere of trust, namely favourable conditions for shaping trust to a particular NGO. Authentic trust is built as a balance between belief in the operation of a cooperating entity and the assessment of a situation which results from cooperation. Authentic trust may be shaped based on experience with a particular subject. NGOs should aim at building both blind trust (not based on experience of cooperation) and authentic trust (which was formed as a result of positive experience of cooperation).

In the case of building relations with other entities, a normative and predictive trust may be indicated. Normative trust is related to the belief that other people behave ethically on account of generally applicable standards. This type of trust comes from a belief that other people will behave ethically, i.e. will behave in a specific manner. Normative trust is a basis for creation of general social trust or the so-called atmosphere of trust. While, predictive trust is a belief in a human and more precisely - prediction that a given person is trustworthy. The operation of NGOs should be based on both normative and predictive trust. Due to a high level of normative and predictive trust, non-profit organisations may shape blind trust which creates conditions for the atmosphere of trust.

Functioning of NGOs is based on cooperation with various entities. Therefore, based on Williamson's research we may distinguish three 
types of trust, i.e. personal trust, calculated trust, and the institutional one (Williamson, 1996).

Personal trust of individuals is based on positive emotions towards the subject. If an individual - recipient of a particular service was satisfied then certainly she/he wanted to purchase the same or another service from a given seller. Individuals loyal towards a specific organisation often treat it specially; they may limit control of its operation or even ignore some failures. In case of trust to an NGO, personal trust plays a special role because cooperating subjects have a chance to achieve advantages from cooperation often after some time and not instantly. This type of trust may be related to a few levels of cooperation, i.e. organisation - recipient of a service, organisation- founder (donors), organisation - volunteers, organisation - society. Personal trust is also important in the case of building general social trust to an NGO. They should aim at building personal trust based on cognitive processes.

One should pay attention to the fact that trust in cooperation is often based on rational presumptions, i.e. own experience and experience of others with a particular subject, mutual profitability of the cooperation and perspective of repeatability of a given activity (Lewicka-Strzałecka, 2003). Based on these presumptions one may distinguish calculated trust. This type of trust is based on generally available information provided by the press, rankings, results of research, or experience. Calculation trust occurs in a cooperation relationship. We should pay attention to the fact that it gains a particular meaning on account of a complex nature of contracts, which may be concluded between cooperating subjects. In case of NGOs, this type of trust is important since services offered by NGOs satisfy the society's needs free, partially free or, fully paid. Recipients of services often do not have complete information on production of a given product and only consume the product. Thus, cooperating subjects sometimes find it difficult to evaluate entirely the NGO's operation or its product. NGOs should aim at building calculated trust based on emotional processes and structures.

Here, we should emphasise the two grounds, where calculated trust and personal trust are important, i.e. organisation - founder and organisation - volunteer. It is important that satisfaction, self-realisation and satisfaction of founders and volunteers were built on the one hand on calculated trust and on the other hand on personal trust. Donors and volunteers should have positive emotions towards a particular organisation and at the same time positive experience from cooperating with it. 
The last type of trust is related to shaping the cooperation relation. It is institutional trust. This type of trust is a derivative of the conditions set forth by the provisions of law. In case of activity of an NGO it gains a special meaning on account of legal provisions, which may define the principles of functioning of these organisations. NGOs should aim at building institutional trust on behavioural mechanisms and not on stereotypes.

The functioning of a given organisation is related to provision of information. Provision of information results from relations inside a given organisation as well as from external relations with it. From the point of view of providing information, trust, which may be shaped through a manner and quality of information, is significant. Two types of trust may be distinguished here: trust based on kindness and on competences (Królak-Wyszyńska). Kindness may be defined as care and motivation to act for the welfare of the other party, which is contrary to opportunistic acts (Grudzewski et al. 2009). We define competences as a set of skills or/and abilities indispensable to do what is necessary (Grudzewski et al., 2009). Both kindness and competences are a basis of functioning of non-profit organisations. NGOs should act in the interest of donors, founders, and subjects to whom they render specific services. In order to achieve particular objectives, an NGO must have particular competences. Based on the so defined concepts of kindness and competences we may attempt to define trust based on kindness and competences.

Trust based on kindness is a type of trust which assumes that an individual will not harm another individual when such possibility occurs. Trust based on kindness lets the person seeking information to ask questions without fear to be laughed at or disrespected. Due to such trust, an individual is able to acquire knowledge, which she/he can use and apply. For building trust based on kindness, such factors as: sensitivity and strong bonds, are crucial. This type of trust is important in case of NGOs. NGOs in the process of determining and realising their objectives take into account not only clients' (recipients') needs but also the needs of founders and the entire society. Due to relevant shaping of their activity, they may create a picture of a caring organisation, founded to execute a specific common objective.

Trust based on competences refers to a situation when there is a conviction that the other person (entity) has relevant knowledge and specific skills in a given subject. Trust of this type enables a unit 
which uses the services to believe that the entity which offers them will carry them out at an appropriate level. Non-profit organisations should shape their activity in such way so that the recipients of their services are convinced that the indicated organisation has relevant competences to offer a particular service.

It may be noticed that people who trust others are more open to social activities and ready to act for the general welfare. On the other hand, mistrustful people are more conservative and careful. A higher level of social trust favours introduction of any social changes. The existing trust reduces uncertainty of functioning of various spheres of social and economic life. Trust may be analysed in three planes, i.e. trust as properties of the exchange relationship, trust as a basis of cooperation, trust as a culture standard.

From the point of view of this study, it is the second ground of the analysis - trust as a basis for cooperation. A suitable level of trust favours development of cooperation while its lack may limit cooperation or increase its costs. It is also worth mentioning that trust may be analysed as some kind of a cultural pattern of a given society (all people trust and I will); an element of the social bond (we may cooperate peacefully because I trust people around me) and as an element of personality (I believe that others act to the best of their possibilities). Building trust as an element of a social bond is certainly a basis for development of trust as cooperation in a given society.

Trust for NGOs should also be considered in two aspects, i.e. as subject trust and object trust.

Subject trust is a belief or conviction that a given institution will carry out specific actions or operations in the future. This type of trust is given by subjects - entities directly or indirectly cooperating with a particular organisation or by subjects which benefit from functioning of an NGO. It may be related to trust to a particular organisation, to some groups of organisations or trust in general to an NGO. Object trust is related to a belief that the intended aim of an organisation will be met.

Object trust to an NGO may be built on two grounds i.e. through performance of tasks (performance) and through accountability. Through performance of tasks, cooperating parties may achieve a particular aim, socially positive or such that raises the quality of life of a given community. Responsibility is related to particular actions namely to a manner of achieving the intended aim. In the case of object trust we may talk about trust based on procedures and blind trust. Procedural 
trust is a form of trust directed to "institutionalised practices or procedures" (Sztompka, 2007). In fact, this task is oriented at procedures or institutions which built it. As a result, we may believe that specific patterns of conduct can enable us to achieve desired results. We find it easier to trust in an $\mathrm{NGO}$, to whom we give $1 \%$ of our income tax, than in other NGOs. It is related to a belief (conviction) that some types of procedures will ensure proper spending of the collected money by the public benefit organisation.

In case of subject trust we should list subjects which may enter into relations with a non- profit organisation. We may use here the concept of the interested parties. According to R.E. Freeman, the term "interested parties" stands for each group or a person, which may influence the realization of the aims of an organisation or whose situation is affected by an organisation which realises its aims (Freeman \& Reed, 1983). Literature includes many classifications of the interested parties' groups of an NGO. We may emphasise here in particular:

- founders, members of an organisation,

- employees and volunteers or guardians - persons who manage organisations,

- recipients of actions (who may also be members of an organisation),

- suppliers:

- entities which give funds and support the activity of organisations (present and possible donors, benefactors, sponsors),

- local government units,

- state administration bodies,

- financial institutions,

- the public (as a common group, from which founders, volunteers, and recipients of actions may be distinguished),

- other third sector organisations ,

- $\quad$ service providers (e.g. delivery companies, banks, event companies, charity companies),

- $\quad$ the society (based on Huczek, 2014, pp. 51-53).

Such division of groups of subjects which enter into relations with a non-profit organisation, enables distinguishing two types of subject trust, i.e. internal trust and external trust. External trust to an organisation may be built by people and entities not related to a given organisation (precisely those which do not directly enter relations with a particular organisation), e.g. by the society. We 
should emphasise that the society may directly benefit from the NGO's functioning e.g. through raising provided social services. A high level of external trust to an NGO has a chance to create convenient conditions for development of an organisation of this type. A non-profit organisation should care for shaping this trust regardless of building other types of trust.

Internal trust may be shaped by people (subjects) who cooperate with a particular organisation. In this case, one should separate trust of people-subjects using services rendered by an NGO (trust of clients - recipients of actions) from the trust of other subjects cooperating with a particular organisation (e.g. trust of benefactors or founders).

Types of trust presented above enable us to separate three dimensions of building trust towards a non-profit organisation i.e. internal dimension, market dimension, and social dimension. The internal trust dimension is related to shaping trust to the employees of an organisation and its volunteers. A high level of internal trust forms foundations for engagement of employees in the process of rendering social services and encourages to suitable cooperation with the environment - both with the recipients of actions, founders, and society. A market dimension of trust is related to shaping trust of recipients of actions delivered by an NGO. It is related to the object trust to an NGO and enables the assessment of trust to a particular non-profit organisation. The last dimension of trust - a social one is related to shaping trust to an NGO in general. The benefactors, public, and society are subjects which shape a social dimension of trust. A high level of social trust to non-profit organisations enables not only realising tasks of particular organisations but also an exchange of information with regard to better satisfaction of social needs.

Trust is an element of the affective component of the attitude towards an NGO. Owing to trust, we may express emotions and feelings in a particular non-profit organisation or to all non-profit organisations. On the other hand, trust is in fact, the essence of functioning of an NGO. Conditions of mistrust disable common realisation of the intended aims of an organisation and finding funds for the realisation of these aims. NGOs may shape the atmosphere of mutual trust in relations with all groups cooperating with them. We may mention here both clients who benefit from actions offered by an NGO and the so-called guardians (managers of organisations), the public (comprising active citizens who affect development and 
functioning of the NGO), and the society in general (recipients of positive effects of the NGO's operation).

\section{TRUST IN NGOS IN POLAND}

The level of trust is systematically investigated in Poland. Research concerning general social trust and trust to different organisations is available. We may indicate, inter alia, studies by CBOS, TNS Global, Social Diagnosis report, analyses of Klon/Jawor, and the results of research in the international cross-section by the EdelmanTrust.

The Polish society has a low level of confidence in authorities and subjects of a public sphere (Figure 1). Moreover, Poles declare a considerably low level of general trust in comparison to other countries (Figure 2). Non-governmental organisations are somewhat more confident in comparison to other institutions operating in Poland.

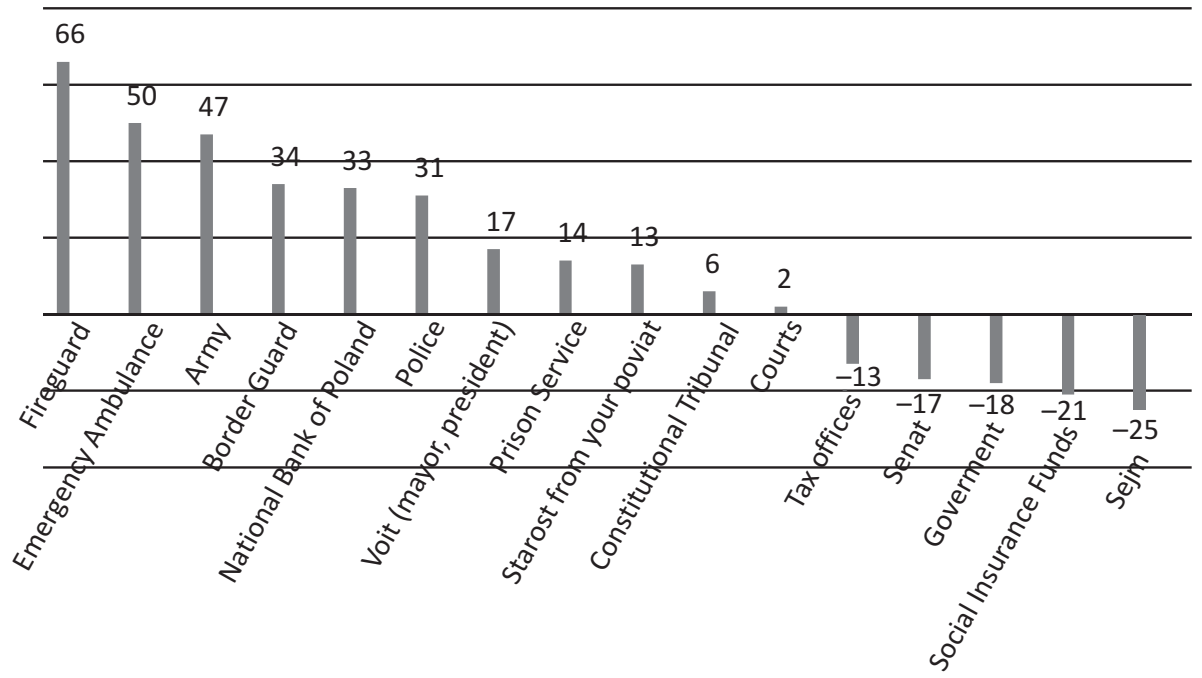

Figure 1. *Net trust to public institutions in Poland 2016

* Net trust in percentage points - Interest of "absolutely yes" responses plus "rather yes" responses minus interest of "absolutely no" and "rather no" responses

Source: Zaufanie do instytucji publicznych porównanie z lat 2006, 2010, 2016 [Trust to public institutions, a comparison from the years 2006, 2010, and 2016]. http://www.tnsglobal. pl/archiwumraportow/files/2016/11/K.068_Zaufanie_do_instytucji_O10a-16.pdf (access: 20.04.2017) 


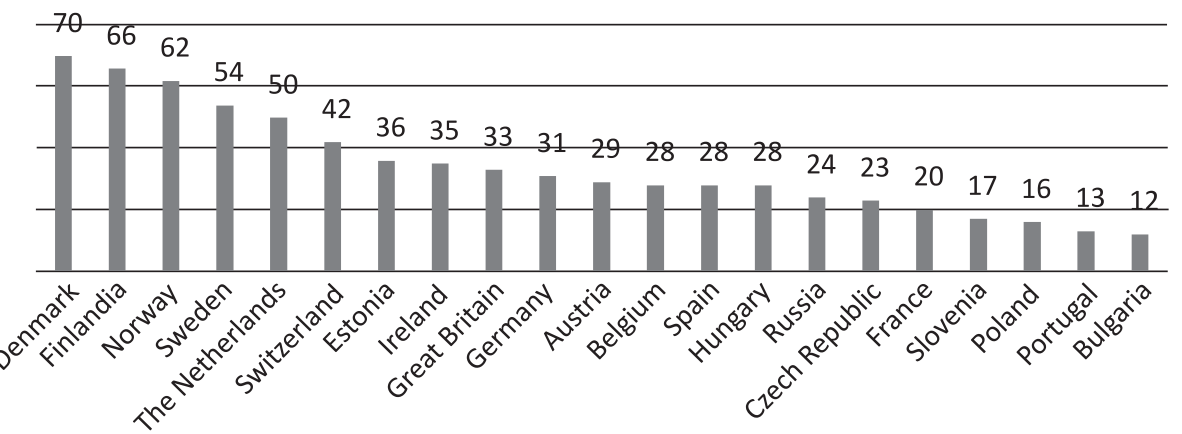

Figure 2. Interest of people aged 16 and over who trust other people comparison of various countries 2014

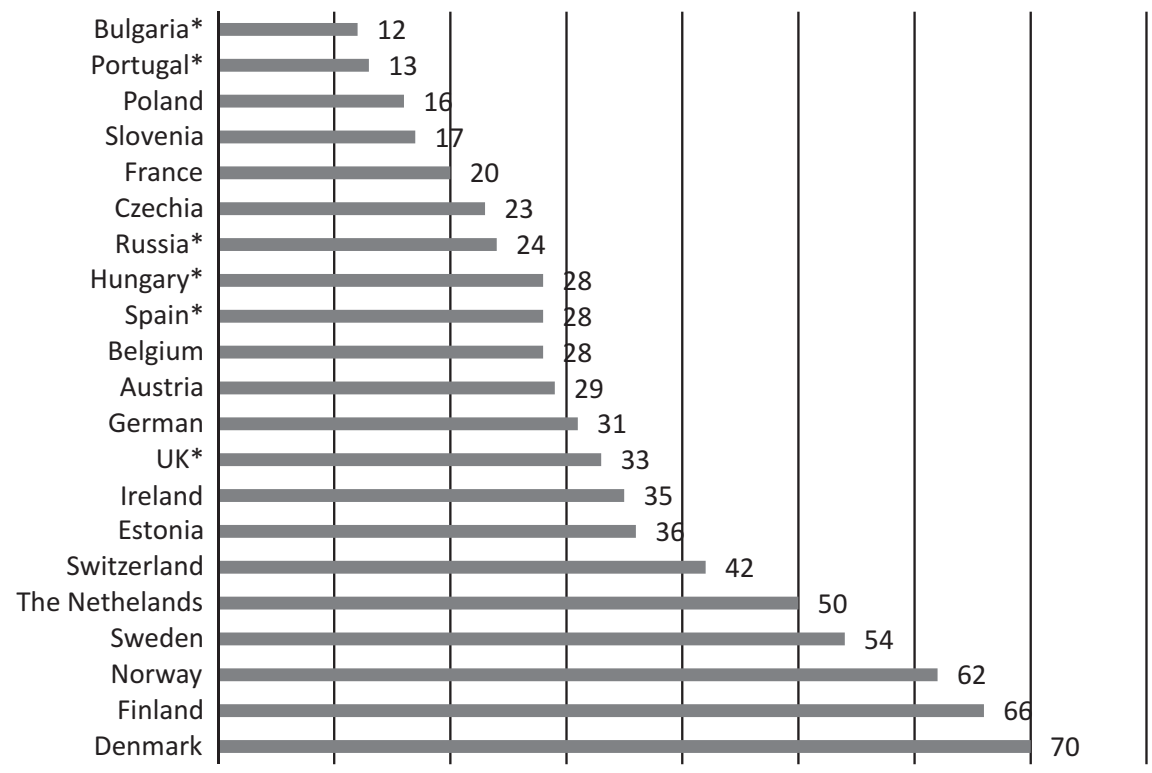

Figure 3. The percentage of people aged 16 or older who trust other people - comparison of various countries in 2014.

*date from 2012

Source: Diagnoza spoleczna 2015 rok, dokument elektroniczny [Social diagnosis 2015, e-document]: http:// www.diagnoza.com/pliki/raporty/Diagnoza_raport_2015.pdf, readout (access: 27.04.2017).

NGOs have a considerably high global level of trust. An index of trust in NGOs according to the Edelman Trust Barometer on the global scale is 53\%. According to the indicated research, trust in NGOs is $48 \%$. In Poland, trust in NGOs dropped by $2 \%$ in 2017 in comparison to 2016 , which complies with a global trend. However, confidence in 
NGOs is still higher than trust to business operating entities. The figure below presents the results of the Edelman Trust Barometer of 2017 concerning trust in NGOs.

Trust to third sector entities in Poland is assessed as considerably high. The data presented by the Centre for Public Opinion Research indicate that three charity organisations with an all-Poland scope i.e. WOŚP, PCK, and Caritas have the highest trust among popular institutions in Poland. In January 2016, 85\% of Poles declared their trust to WOŚP [The Great Orchestra of Christmas Charity], 83\% to Caritas and 79\% to PCK [The Polish Red Cross] respectively (Zaufanie społeczne/Public trust, 2016, CBOS).

Trust in NGOs Declines

Percent trust in NGOs, and change from 2016 to 2017

\section{$\checkmark$} NGOs less trusted than business in 11 countries

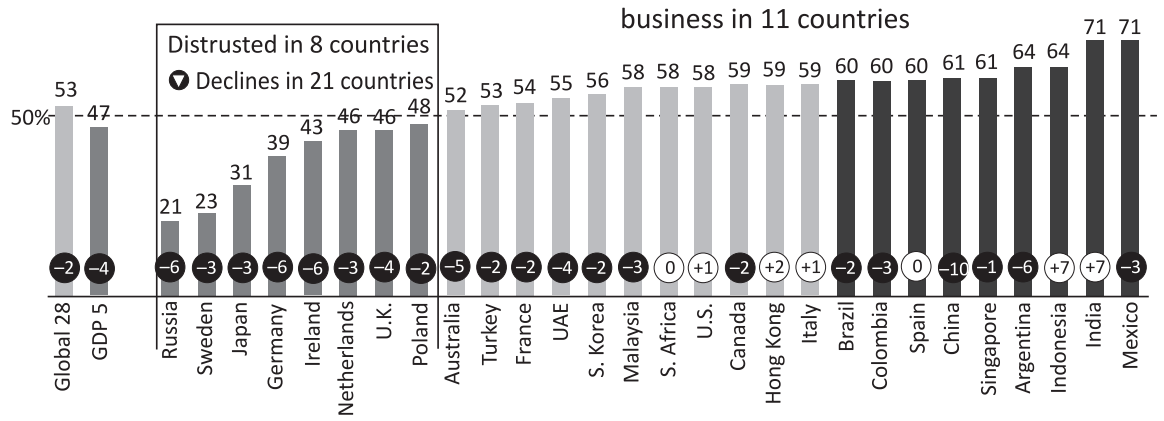

पDistrust $\square$ Neutral ITust

- + Y-to-Y Change

Figure 4. Trust in NGOs acc. to the Edelman Trust Barometer in 2017

Source: Edelman Trust 2017. Report, e-document, http://www.edelman.com/trust2017/ (access: 27.04.2017).

Presenting data, which concern the level of trust for people who work socially in the place of residence, seems to be interesting. People working for the benefit of a local society declare a higher level of trust (61\%) than mistrust (8\%). Surprisingly, a big group of people who work socially have no opinion on trust - 31\% (Zaufanie społeczne/Social trust, 2016, CBOS).

Other research also shows that NGOs enjoy a considerably greater social trust. The report from the research on Image of NGO developed by the Klon/Jawor Association in 2015 showed that $48 \%$ of Poles trust third sector organisations. Foundations are the most trusted (56\%) and associations a little bit less (50\%). According to the data from the report, trust to NGOs raises along with the level of education and as a result of meeting a specific organisation. The figure presented 
below presents the results of research of the Klon/Jawor Association. A similar research made at the request of the Klon/Jawor Association shows that in 2017 associations were the most trusted (60\%). On the other hand, in case of NGOs and associations, trust was declared by $55 \%$ and $53 \%$ of the investigated persons respectively.

The report on Image of NGOs includes an analysis of the factors which may shape trust to NGOs according to Poles. The following elements were mentioned here:

- effects (results) of operation - organisations which were successful inspire trust,

- objective of operation - social aims are especially important,

- knowing people engaged in activities of an organisation combined with an openness of an organisation to new people (possible beneficiaries, members, and volunteers),

- fairness and transparency of an organisation's operation (related to showing the place where the organisation operates, manner of financing, and manner of operation),

- evaluation of the operation of an organisation through the perspective of current successes in the context of an organisation's operation,

- building accountability of an organisation based on a famous person and presence of visibility of the organisation's operation in the domestic media,

- scale of operation - big domestic organisations are trusted more - it proves professionalism and transparent operation,

- presentation of specific objectives of operation and clear communication concerning the manner of operation (including plans of operation and a precise group of recipients),

- cooperation with trustworthy partners (companies, offices, etc.),

- high skills of employees combined with mediocre remuneration (based on the report from Klon/Jawor Image of NGO, 2015).

The indicated elements show the grounds for shaping trust in an NGO. They cover three dimensions of trust indicated above (inside an organisation, market, and social). Highly assessed from the point of view of trust are organisations with specific results of operation, which act fair and transparent using the work of diligent and fair employees and volunteers. Unfortunately, it is easier to inspire trust in case of NGOs operating on the national scale with assistance of famous people than local organisations. 


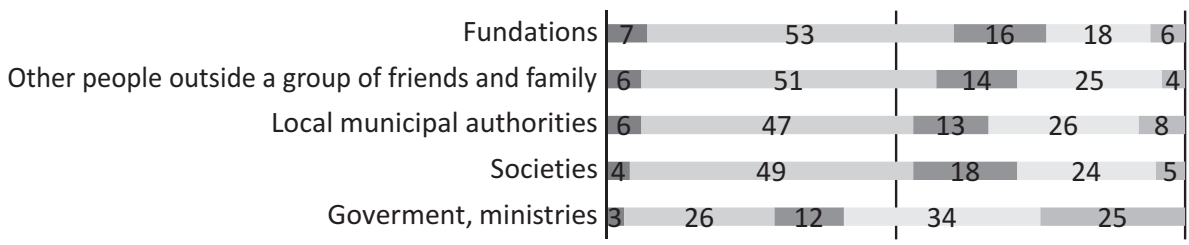

I trust definitely $\quad$ I rather trust I do not know/hard to say

Figure 5. Trust to the indicated groups, organisations, institutions based on Klon/Jawor Image of NGO

Source: file://D:/Documents/Archiwum/Uniwersytet/Konferencja\%20ISP/2017/Zaufanie\%20 do\%20NGO/raport_wizerunek.pdf (access: 20.04.2017)

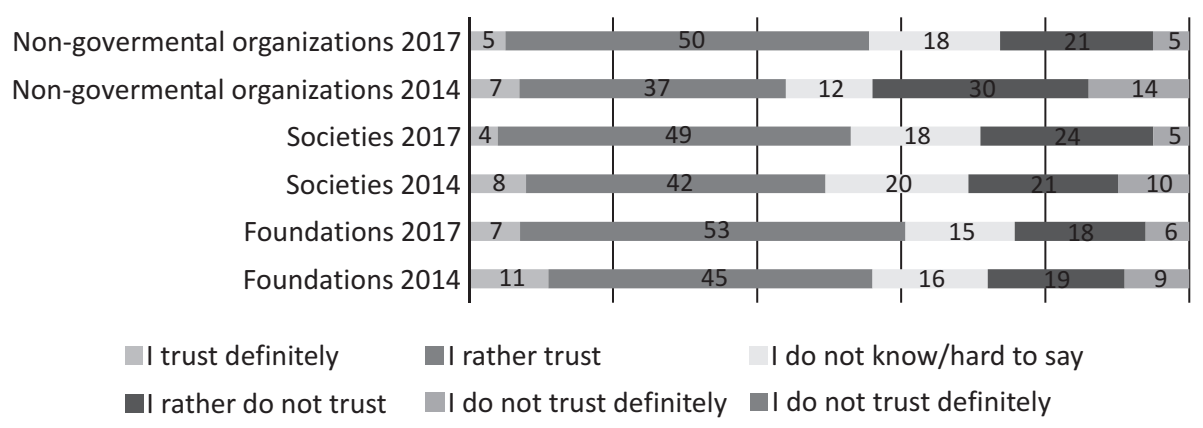

Figure 6. Trust in foundations, associations and NGOs in 2014 and 2017 Source: http://fakty.ngo.pl/wiadomosc/2022437.html (access: 20.04.2017).

\section{CONCLUSION}

Third sector organisations through skills of reacting to social problems and adjusting to the present needs of various societies are significant participants of social life. In particular, closeness to local societies enables reacting to the needs and finding skilful solutions to problems. Non-profit organisations should act, so that the interesting parties have full confidence in the objectives of their operation, competences of cooperating people and the manner of functioning of a given organisation. Analysis of trust in a non-profit organisation should be made in many dimensions.

Social trust should be a fundamental capital of NGOs. Third sector organisations are highly assessed by the society. It seems that one of 
the best methods of shaping a positive image of an organisation of this type should be building trust to those organisations. Trust should be shaped towards various groups of interested parties of NGOs. Recipients of provided actions, benefactors, founders, volunteers, and employees are particularly important here. General trust to NGOs may be shaped through building trust in the indicated groups.

With regard to the service nature of operation of a third-sector organisation trust plays a special function. Trust enables shaping relevant conditions of operation between a non-profit organisation (its employees, volunteers, and founders) and the recipients of actions. Currently, we have to distinguish between operating non-profit organisations and a great number of organisations. They should operate, so that they can efficiently realise their statutory objectives to which they were convened. On one hand, they have to focus on actions which satisfy important social needs, on the other hand they have to act, so that they can draw attention of possible clients, both recipients of services, volunteers as well as donors and founders. Building trust seems to be helpful in realising these purposes. The actions which built trust should be continuous and systematic and they should aim at creating and maintaining mutual trust between a given organisation and the society. Building trust should take place through building competences (of an organisation and its employees), showing kindness and engagement, and proving positive intentions. We should indicate that third sector organisations must care for building not only trust in a particular organisation, but create conditions for the atmosphere of trust. A suitable atmosphere of trust will create conditions for raising trust in non-profit organisations as a whole sector. An NGO's success depends on its external subjects, whose high level of trust to non- profit organisations may have a key meaning for the development and obtaining funds for operation. Only non-commercial organisations which have a high level of social trust can be successful.

The article identified the confidence building platforms and types of trust that NGOs may have. Individual non-governmental organisations need to consider trusting at different levels. It would be interesting to examine the importance of individual types of trust for different types of NGOs, on the basis of the scope of activity, donors, service recipients, and the purpose of activities. 


\section{REFERENCES}

Biesiok, G.(2013) Zaufanie jako czynnik sukcesu satysfakcji pracowników, Zeszyty Naukowe. Organizacja i Zarządzanie, Politechnika Łódzka, z. 51.

Bogacz-Wojtanowska, E. (2008), Funkcjonowanie przedsiębiorstwa społecznego w otoczeniu. Kwartalnik Ekonomia Społeczna, 2(3).

Bogacz-Wojtanowska, E. (2013). Zdolnosci organizacyjne a wspótdziałanie organizacji pozarzadowych. Kraków: Instytut Spraw Publicznych Uniwersytetu Jagiellońskiego.

Covey, S. \& Merrill R. (2008). The Speed of Trust: The One Thing that Changes Everything. CoveyLink LLC.

Filipiak, B. \& Ruszała, J. (2009). Instytucje otoczenia biznesu. Rozwój, wsparcie, instrumenty. Warszawa: Difin.

Freeman, R.E. \& Reed, D.J. (1983). Stakeholders and shareholders: A new perspective on Corporate. California Management Review, 25.

Gambetta D. (1988), Trust. Making and Breaking Cooperative Relations, Basil Blackwell Ltd., Oxford, Massachutess

Grudzewski, W., Hejduk, I., Sankowska, A. \& Wańtuchowicz, M. (2007). Zarzadzanie zaufaniem w organizacjach wirtualnych. Warszawa: Difin.

Grudzewski, W., Hejduk, K., Sankowska, A. \& Wańtuchowicz, M. (2009). Zarzadzanie zaufaniem w przedsiębiorstwie. Kraków: a Wolterss Kluwer Business,.

Hardin, R. (2009). Zaufanie. Warszawa: SIC.

Hadryś, A. (2008). Czynnik zaufania w funkcjonowaniu firm rodzinnych, [w:] Materiaty Krakowskiej Konferencji Młodych Uczonych, Kraków, Fundacja Studentów i Absolwentów Akademii Górniczo-Hutniczej w Krakowie ACADEMICA, Grupa Naukowa Pro Futuro, s. 425-430.

Huczek, M. (2014). Zarządzanie organizacjami pozarządowymi. Zeszyty Naukowe Uniwersytetu Przyrodniczo-Humanistycznego w Siedlcach. Administracja i Zarzadzanie, 101.

Janoś-Kresło, M. (2002). Ustugi społeczne w procesie przemian systemowych $w$ Polsce. Warszawa: SGH.

Kapuścik, E. (2015). Dylematy nadużycia zaufania interorganizacyjnego w organizacjach publicznych. Zeszyty Naukowe Wyższej Szkoty Humanitas, 2015(2).

Krzyżanowska, M. (2000). Marketing organizacji niekomercyjnych. Warszawa: Wydawnictwo Wyższej Szkoły Przedsiębiorczości i Zarządzania im. L. Koźmińskiego.

Lewicka-Strzałecka, A. (2003). Zaufanie w relacji konsument-biznes. Prakseologia, 143. Lewis, D. \& Weigert A. (1985). Trust as a Social Reality. Social Forces (Oxford University Press), 63(4), 967-985. 
Mayer, R.C., Davis, J.H. \& Schoorman, F.D. (1995). An Integrative Model of Organizational Trust. Academy of Management Review, 20(3).

Mika, B.(2009). Sieć zaufania. Toruń: ECE.

Paliszkiewicz, J. (2013). Zaufanie w zarzadzaniu. Warszawa: Wydawnictwo Naukowe PWN.

Pawłowska, E. (2015). Organizacje pozarządowe a kapitał społeczny. Zeszty Naukowe Politechniki Ślqskiej. Organizacja i Zarzadzanie, 77, Kol. 1927.

Praszkier, J.(2007). Zaufanie jako osiowy czynnik dynamiki kapitału społecznego. Trzeci Sektor, 10 (lato).

Sankowska, A. (2009). Organizacja wirtualna. Koncepcja i jej wptyw na innowacyjność. Warszawa: WAiP.

Sankowska A. (2012). Zaufanie a transfer wiedzy, Przeglad organizacji, nr 7, 3-6. Sargeant, A. (2004). Marketing w organizacjach non profit. Kraków: Oficyna Ekonomiczna. Sztompka, P., (2007). Zaufanie. Fundament społeczeństwa. Kraków: Znak.

Williamson, O.E. (1996). The Mechanisms of Governance. New York: Oxford University Press.

\section{Electronic literature}

An NGO Training Guide for Peace Corps Volunteers, http://files.peacecorps.gov/ multimedia/pdf/library/M0070_all.pdf (access: 11.11.2011).

Hausner, J. , Lauriasz, N. \& Mazur S. Przedsiębiorstwo społeczne - konceptualizacja. In: J. Hausner (ed.), Zarzadzanie podmiotami ekonomii społecznej, skrypt 2. Kraków: MSAP UE. http://www.e-gap.pl/PUBLIKACJE/es\%20skrypt2.pdf (access: 22.10.2011).

Iwankiewicz-Rak, B. Problemy zarządzania w organizacjach pozarządowych. http://www. isp.org.pl/kompas/files/20512444270426862001201857658.pdf (access: 3.01.2012).

Królak-Wyszyńska K., Pomocna dłoń zaufania, http://kadry.nf.pl, (access:10.04.2012.)

Poleszczuk, G. Podstawy public relations organizacji społecznych. In: J. Hausner (ed.), Zarzadzanie podmiotami ekonomii społecznej, skrypt 2. Kraków: MSAP UE, http://www.msap.uek.krakow.pl/doki/publ/es_zarzadzanie.pdf (access: 2.04.2017)

Polacy o Trzecim sektorze. http://osektorze.ngo.pl/wiadomosc/710730.html (access: 3.01.2012).

Raport Edelman Trust 2017. http://www.edelman.com/trust2017/ (access: 27.04.2017). Wizerunek organizacji pozarządowych. Raport z badań, 2015 rok. file://D:/Documents/ Archiwum/Uniwersytet/Konferencja\%20ISP/2017/Zaufanie\%20do\%20NGO/ raport_wizerunek.pdf (access: 20.04.2017).

Zaufanie społeczne, luty 2016. http://www.cbos.pl/SPISKOM.POL/2016/K_018_16. PDF (access: 25.04.2017). 


\title{
DETERMINANTY KSZTAKTOWANIA ZAUFANIA DO ORGANIZACJI POZARZA_DOWYCH (NGO)
}

\begin{abstract}
Abstrakt
Tło badań. Analiza organizacji trzeciego sektora wymaga wprowadzania nowych pojęć do opisywania i wyjaśniania zasad ich funkcjonowania. Podmioty ekonomii społecznej są zmuszone do zwracania coraz większej uwagi na relacje z podmiotami współpracującymi, tzw. interesariuszami. Budowanie zaufania wydaje się być sposobem ułatwiajacym współpracę, realizację zamierzonych celów oraz rozwój organizacji. Ważną cechą organizacji trzeciego sektora jest to, iż powstają one w wyniku oddolnej inicjatywy obywatelskiej, tzn. ludzi pragnących osiagnąć określony cel. Budowanie optymalnych złożonych relacji z interesariuszami wydaje się głównym sposobem na realizację zamierzonych celów podmiotów trzeciego sektora. Ten cel może być skutecznie osiagnięty, gdy współpraca opiera się na zaufaniu. Zaufanie wydaje się nie tylko determinantem kształtowania działalności NGO, ale również efektem ich funkcjonowania. W artykule postawiono tezę, że zaufanie jest istotnym czynnikiem decydującym o sukcesie działania organizacji non profit.
\end{abstract}

Cel badań. Celem artykułu jest wskazanie miejsc - relacji powstawania zaufania, systematyka rodzajów zaufania oraz określenie determinant kształtowania zaufania do organizacji pozarządowych. Przedstawiono propozycję konceptualizacji pojęcia zaufania do NGO z uwzględnieniem czynników jego kształtowania.

Metodologia. Dla potrzeb analizy zaufania do NGO przeprowadzono analizę literatury dotyczącej trzeciego sektora, zarządzania i zaufania. Przegląd umożliwił odniesienie wiedzy do określenia czynników kształtowania zaufania do NGO. Analiza literatury została uzupełniona o przegląd badań dotyczaccych warunków funkcjonowania i oceny działalności podmiotów trzeciego sektora w Polsce.

Kluczowe wnioski. Przegląd literatury umożliwił usystematyzowanie pojęcia zaufania do organizacji trzeciego sektora. Konceptualizacja pojęcia zaufania do NGO wskazała płaszczyzny kształtowania zaufania oraz potrzebę dalszej systematycznej analizy zaufania do podmiotów działających w trzecim sektorze.

Słowa kluczowe: zaufanie, NGO, trzeci sektor, zaufanie do organizacji pozarządowych 